\title{
Laminar burning velocity of ethanol premixed combustion enriched with liquefied petroleum gas (LPG)
}

\author{
Muh Nurkoyim Kustanto ${ }^{1,2}$, \\ I Nyoman Gede Wardana ${ }^{2}$, \\ Mega Nur Sasongko², \\ Lilis Yuliati $^{2}$ \\ ${ }^{1}$ Department of Mechanical Engineering, \\ Jember University, Indonesia \\ ${ }^{2}$ Department of Mechanical Engineering, \\ Brawijaya University, Indonesia \\ E-mail kustanto1969@gmail.com
}

The laminar burning velocity of ethanol premixed combustion enriched with liquefied petroleum gas (LPG) has been studied experimentally. The study was conducted in a cylindrical combustion chamber, and combustion model was spherically expanding flame. The results showed that the laminar burning velocity of ethanol enriched with 5-10\% LPG is higher than that of pure ethanol and that of pure LPG. This is due to the formation of $\mathrm{H}$ and $\mathrm{OH}$ radicals in the preheating zone, where the reaction occurs to form $\mathrm{H}_{2} \mathrm{O}$ and release heat. It raises temperature in the preheating zone which contributes to increase in the laminar burning velocity.

Keywords: ethanol, LPG, laminar burning velocity, premixed combustion

\section{INTRODUCTION}

Ethanol was renewable fuel as a potential substitute for fossil fuels [1]. This was due to the availability of abundant raw materials, and its production process was simple, easy and cheap [1-4]. For that reason the combustion characteristics of ethanol are important to understand, both as pure ethanol fuel or blended with other fuels. In this study, ethanol was enriched with LPG because it has a flash point and atomic weight almost the same as ethanol, in addition to a high combustion energy content. Several studies related to the combustion of ethanol and LPG have been done. Liao et al. [5] investigated the laminar burning velocity in premixed combustion of pure ethanol with increase in the initial temperature. Research on the com- bustion of pure ethanol was also carried out by Egolfopoulos [6]. The research was carried out by comparison of combustion in pure ethanol in experiments with numerical calculation results. Research on the combustion of ethanol and iso-octane mixture done by Broustail et al. [7] was examined by using sphericallly expanding flames in a cylindrical combustion chamber. Turner et al. [8] examined the performance of the combustion of ethanol mixture with gasoline. Al-lwayzy et al. [9] examined the diesel engine performance fuelled with microalga oil and ethanol blended. Patra et al. [10] studied combustion characteristics of kerosene ethanol blend. Research on pure LPG combustion performed by Razus et al. [11] compared between experimental and computational results. Liao et al. [12] 
also conducted a study to determine the Markstein numbers and laminar burning velocity for combustion of LPG-air. Yun et al. [13] perform numerical analysis of catalytic converter on liquefied petroleum gas engine. Lee et al. [14] examined the combustion characteristics of liquefied petroleum gas - biodiesel mixed fuel. From the previous experimental studies, almost none results are found on the combustion characteristics of ethanol-LPG mixture. Therefore, this study discusses the laminar burning velocity of ethanol combustion enriched with liquefied petroleum gas (LPG). The objective of this study was to measure the laminar burning velocity of ethanol-LPG enriched combustion with photographic technique using a high speed camera. The research was conducted to provide information about the combustion of ethanol enriched with LPG.

\section{EXPERIMENTAL METHODS}

\section{Experimental equipment}

The combustion of premixed fuel-air was done in a cylindrical combustion chamber as illustrated in Fig. 1a. The combustion chamber the diameter and length of which was $10.8 \mathrm{~cm}$ and $17 \mathrm{~cm}$, respectively, was made of PVC material. One side of the chamber was closed with acrylic material that served as a spy hole for a high speed camera Casio EXILIM EX-FC100, which was set at a speed of $420 \mathrm{fps}$, while the other side was mounted a moveable cover. The camera has been calibrated using a laboratory method by comparing the captured image and actual size. The resolution of the high speed camera was $224 \times 168$ pixels. From this resolution it was found that the deviation of radius measured from the photographs was $1.5 \%$. Figure $1 \mathrm{~b}$ presents the arrangement of the test equipment. The premixed air-fuel was filled into the combustion chamber through the safety valve. A high voltage coil system with a battery power supply was used to produce a spark in the combustion chamber. Flame diameter measurements were performed when the flame began to occur until the diameter of $50 \mathrm{~mm}$; it was intended to reduce the influence of the wall. Electrical resistance due to changes in the number of radicals was measured by an ion sensor. It consisted of two parallel plates within $1 \mathrm{~mm}$ having the width and length of $8 \times 45 \mathrm{~mm}$. The ion sensor was connected to an electronic circuit to convert electrical resistance into voltage and then connected to the computer as the processing and data storage.

Fuel tested in this study was ethanol enriched with liquefied petroleum gas (LPG) of 0\% (E100), 5\% (E95), 10\% (E90), 15\% (E85), 20\% (E80), and

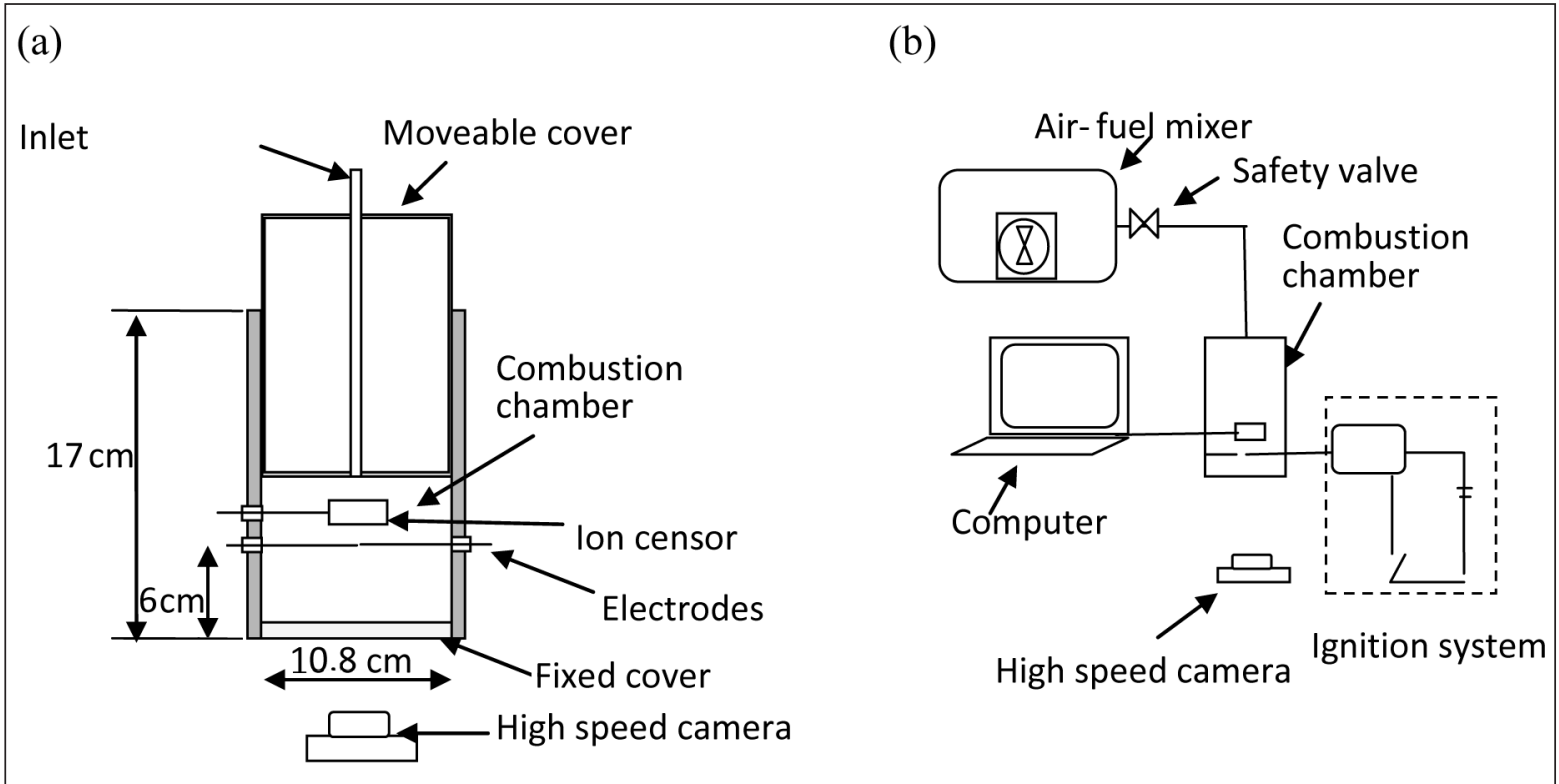

Fig. 1. Scheme of experimental apparatus: (a) combustion chamber, (b) arrangement of test equipment 
$100 \%$ LPG. LPG composition is shown in Table 1, while ethanol used had the purity of $99.7 \%$.

Table 1. LPG composition

\begin{tabular}{c|c|c|c|c}
\hline Items & $\mathbf{C}_{2} \mathbf{H}_{6}$ & $\mathbf{C}_{3} \mathbf{H}_{8}$ & $\mathbf{C}_{4} \mathbf{H}_{10}$ & $\mathbf{C}_{5} \mathbf{H}_{12}$ \\
\hline Volume fraction \% & 0.15 & 51.2 & 47.3 & 1.35 \\
\hline
\end{tabular}

\section{Calculation of laminar burning velocity}

Laminar burning velocity in the spherically expanding flames can be derived from the results of a high speed camera photography. The stretched flame speed $\left(S_{n}\right)$ can be derived from the increase in the radius of the flame divided by increment of time [15]:

$$
S_{n}=d r_{u} / d t
$$

where $r_{u}$ is the radius of the flame and $t$ is the time. Flame stretch rate $(\alpha)$ is defined as [16]:

$$
\begin{aligned}
& \alpha=d(\ln A) / d t \\
& \alpha=(d A) /(A . d t),
\end{aligned}
$$

where $A$ is a spherical area, so the rate of flame stretch could be simplified to

$$
\alpha=\left(2 / r_{u}\right)\left(d r_{u} / d t\right)=2 S_{n} / r_{u} .
$$

There is a linear relationship between flame speed and stretch length Markstein $L_{b}$ expressed as

$$
S_{L}-S_{n}=L_{b} \alpha,
$$

where $S_{L}$ is unstretched flame speed which equals $S_{n}$ at $\alpha=0$. Unstretched burning velocity $U_{L}$ is derived from $S_{L}$ as

$$
U_{L}=S_{L}\left(\rho_{b} / \rho_{u}\right),
$$

where $\rho_{b}$ is the burned gas density and $\rho_{u}$ is the unburned gas density.

\section{RESULTS}

Figure 2 is a photographic image of a stoichiometric mixture of LPG, E100, E90, E80. It is shown that the flame radius increased with increasing time.

Combustion started at $2.4 \mathrm{~ms}$ and continued to evolve with time. Stretched flame speed was estimated from the radius of the spherical flame divided by time. Figure 3 shows the stretched flame speed for different fuel compositions, with equivalent ratios from 0.8 to 1.4 .

\section{(a)}
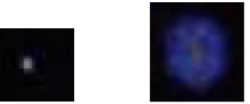

$(2.4 \mathrm{~ms})(7.1 \mathrm{~ms})$

(c)

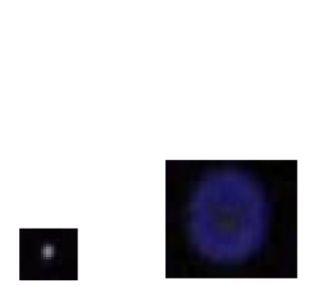

$(2.4 \mathrm{~ms}) \quad(7.1 \mathrm{~ms})$

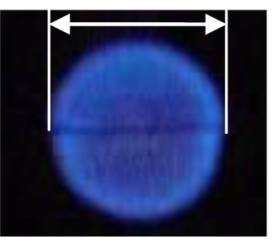

$(11.9 \mathrm{~ms})$

$66.3 \mathrm{~mm}$

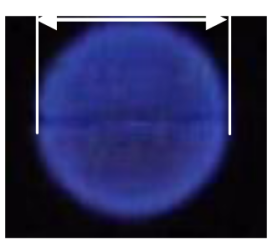

$(11.9 \mathrm{~ms})$

(b)

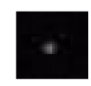

$(2.4 \mathrm{~ms})$

(d)

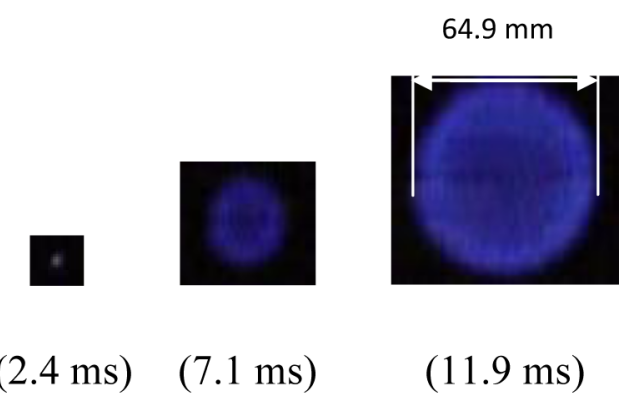

Fig. 2. Flame propagation in a stoichiometric mixture of (a) LPG, (b) E100, (c) E90, (d) E80 


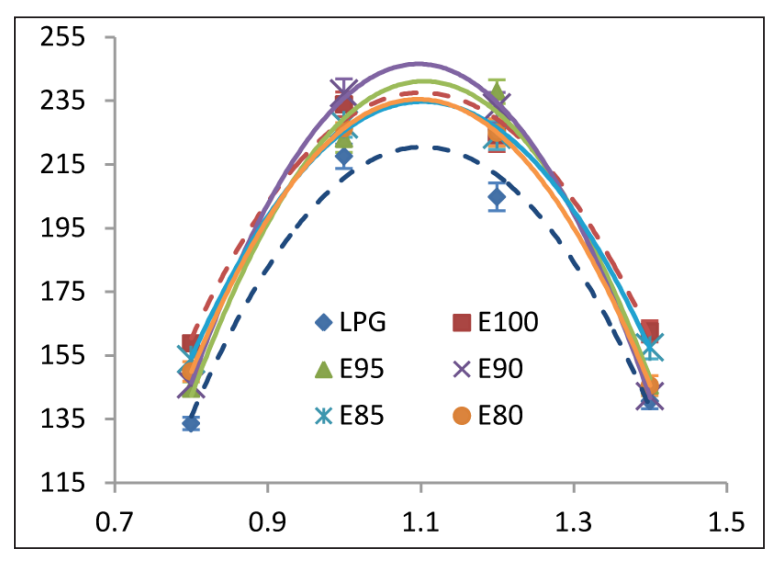

Fig. 3. Stretched flame speed $\left(S_{n}\right)$ of various fuel compositions

The flame speed of pure ethanol (E100) is higher than the flame speed of pure LPG (LPG). Fuels with other compositions have flame speed between LPG and E100, except for the compositions E95 and E90 which have higher flame speed than E100.

Figure 4 shows $S_{n}$ versus $\alpha$. For the mixture with the equivalent ratio $(\phi)$ of $0.8,1.0$, and 1.2 , the gradient of $S_{n} / a$ for all fuel compositions is negative. This means that the flame speed increases with the increase in diameter of the flame. In contrast, a rich mixture with the equivalent ratio $(\phi)$ of 1.4 has a positive gradient of $S_{n} /$ a, except for E90 and E95 which have a negative gradient of $S_{n} / \alpha$ even with a very small angle.

The unstretched flame speed $\left(S_{L}\right)$ was obtained from the value of $S_{n}$ at $\alpha=0$ as in Fig. 4 (see Eq. (4)). Then, the laminar burning velocity $\left(U_{L}\right)$ was estimated from equation (5) as in Fig. 5.

Figure 5 shows that the lowest burning velocity occurred in pure LPG and the higher burning velocity was in E90. This is in accordance with

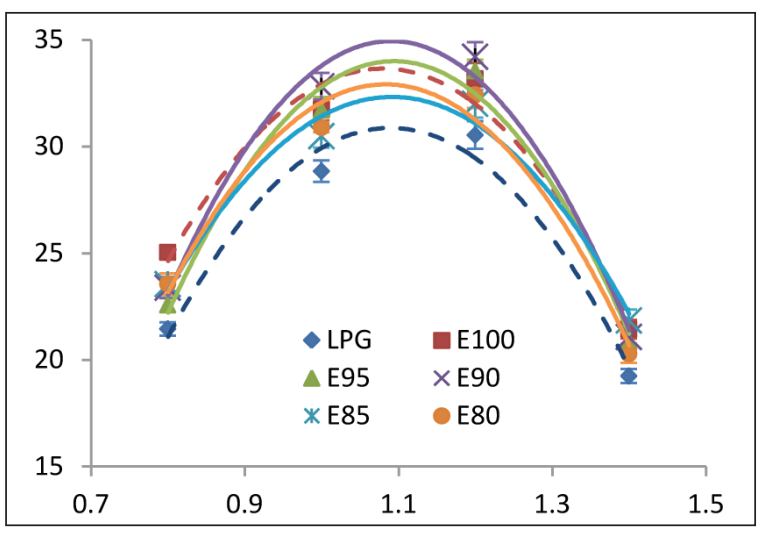

Fig. 5. Laminar burning velocity $\left(U_{L}\right)$ of various fuel compositions

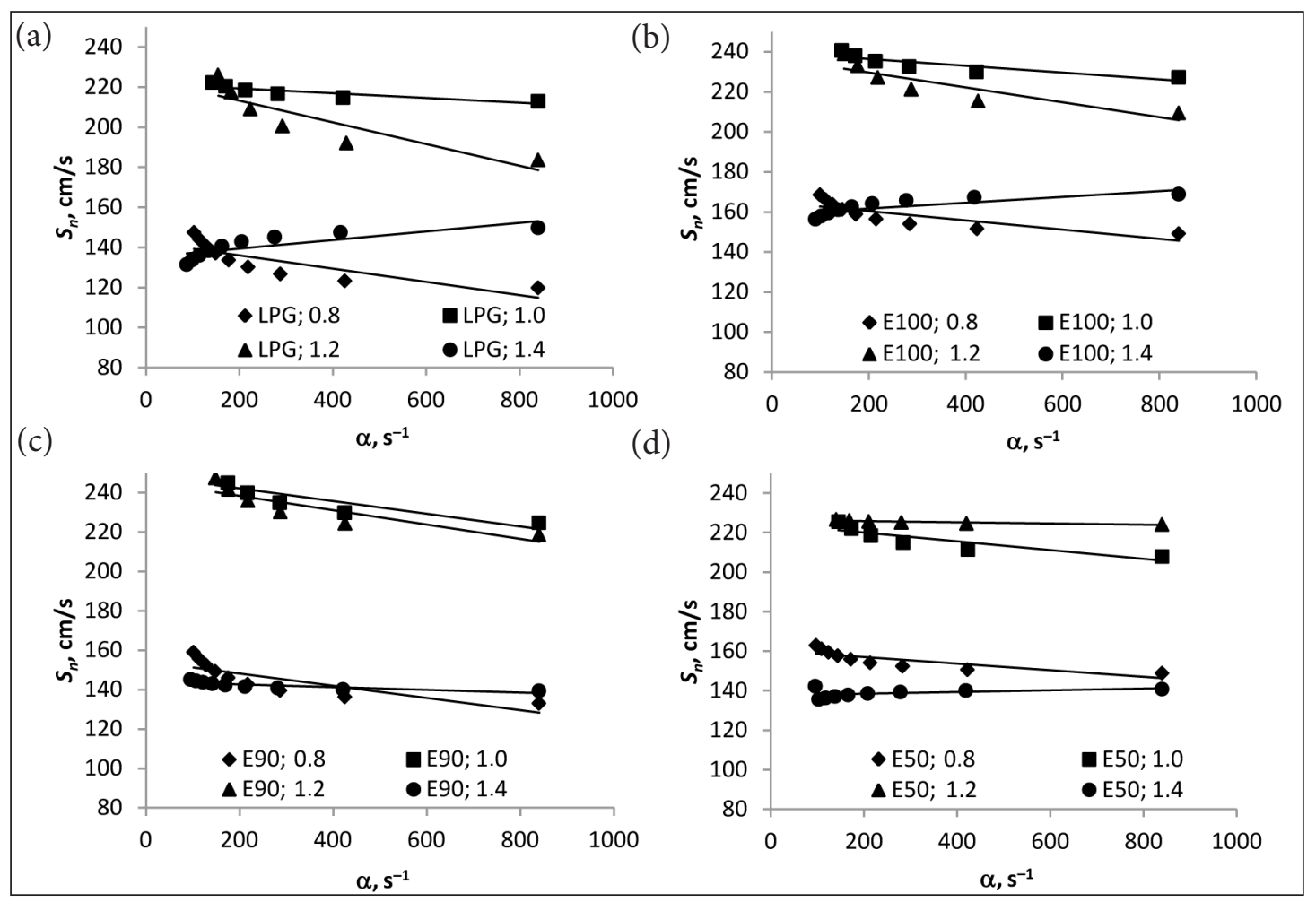

Fig. 4. Stretched flame speed $\left(S_{n}\right)$ versus stretch rate (a): (a) LPG, (b) E100, (c) E90, (d) E80 
those shown in Fig. 4. Fuel with the highest laminar burning velocity occurred at E90 followed by E95. While the fuel with other compositions had laminar burning velocity between ethanol and LPG.

The present data along with the data from other experiments is shown in Fig. 6. It is shown that the laminar burning velocity of ethanol is higher than that of LPG. The data of Liao et al. [5] is greater than the present data. The LPG laminar burning velocity of Liao et al. [12] is higher, due to the higher initial temperature.

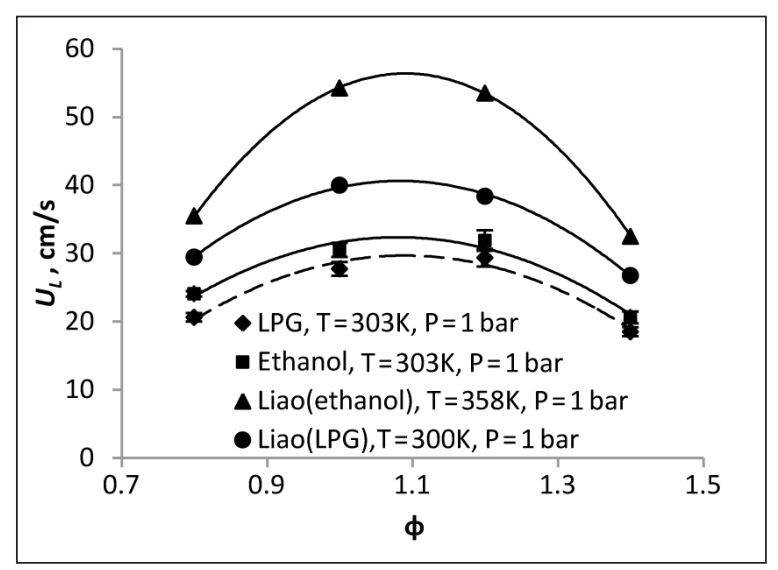

Fig. 6. Laminar burning velocity $\left(U_{L}\right)$ for pure fuel

The relationship between the concentration of radicals (in volts) and equivalent ratios is shown in Fig. 7. It shows that for pure fuel, LPG radicals concentration is higher than that of ethanol. Ethanol enriched with LPG has the radicals concent-

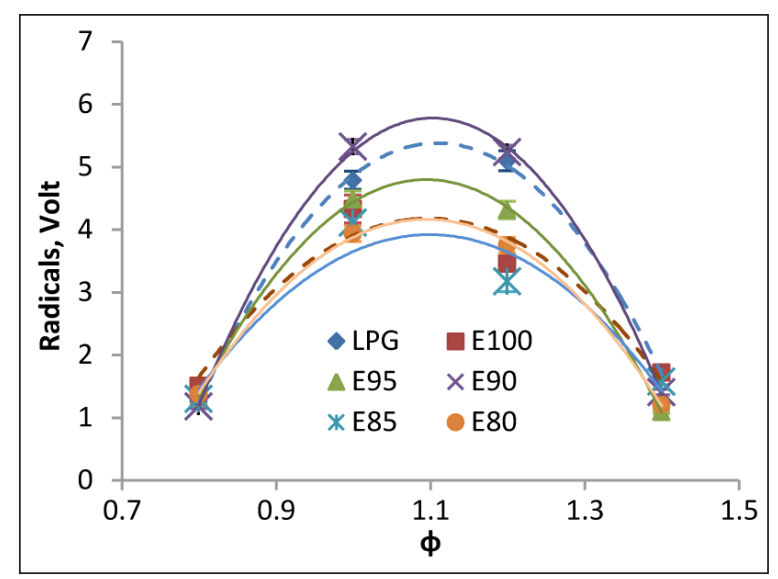

Fig. 7. The relationship between radicals concentration and equivalent ratio ration between pure fuels, except for E90 and E85. E90 has the highest of radicals concentrations, exceeding LPG, conversely E85 has the lowest of radicals concentrations compared with other compositions.

\section{DISCUSSION}

From above data it is clear that combustion characteristics of LPG and ethanol were somewhat different, due to the presence of hydroxyl group $(\mathrm{OH})$ [17] in ethanol which was not found in LPG. During combustion, premixed flame sheet thickness which is in the order of magnitude of $1 \mathrm{~mm}$ is composed by the preheat zone and the reaction zone, as can be seen in Fig. 8a [18]. The distribution of fuel, product, temperature and number of reactions are represented by the solid line. The combustion of fuel containing $\mathrm{C}$ and $\mathrm{H}$ bonds tends to break up on $\mathrm{C}-\mathrm{C}, \mathrm{C}-\mathrm{H}$, and $\mathrm{O}=\mathrm{O}$, whereas that containing $\mathrm{C}, \mathrm{H}$, and $\mathrm{O}$ bonds tends to break up on $\mathrm{C}-\mathrm{C}, \mathrm{C}-\mathrm{OH}, \mathrm{C}-\mathrm{H}$, and $\mathrm{O}=\mathrm{O}$, respectively [19]. Since the bonding

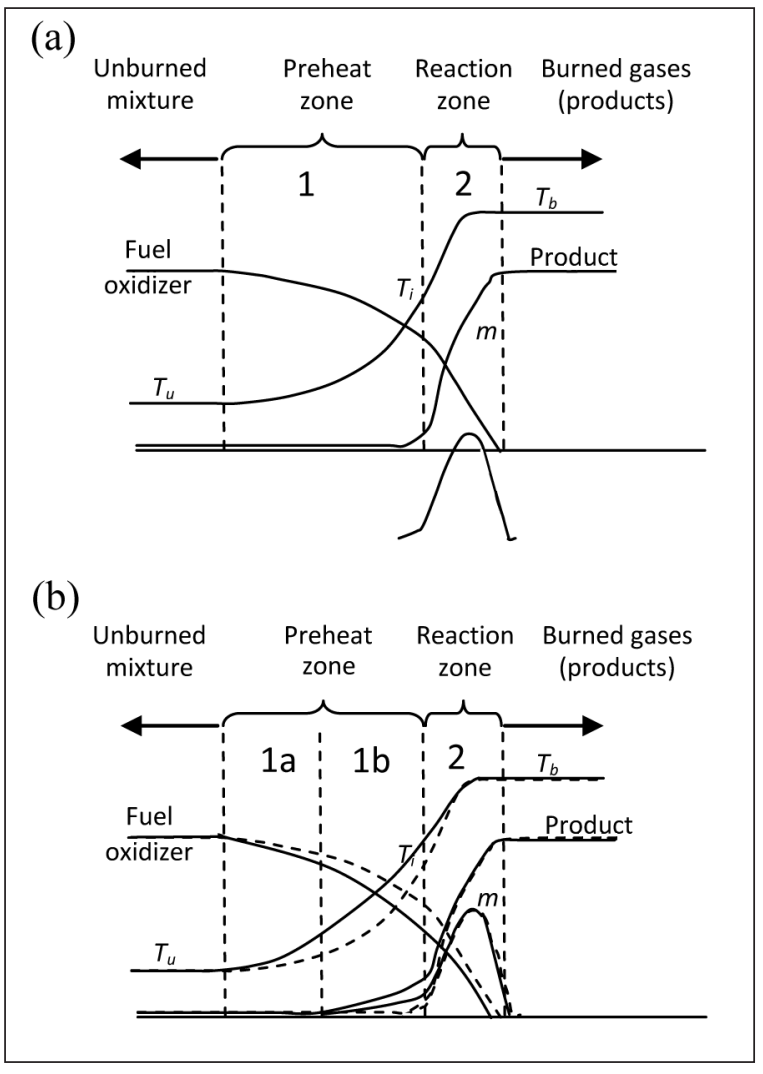

Fig. 8. Laminar flame structure: (a) existing structure, Mahalway [12], (b) proposed structure 
energy of these elements is widely varied; therefore, the flame was proposed to be divided into three zones, as illustrated in Fig. 8b. The 1a zone is also called the preheat zone, in which there were external heating and chemical bonds dissociation. The $1 \mathrm{~b}$ zone is called the partial preheating zone. In this zone, internal heating also occurs due to chemical reactions. The 2 zone is the reaction zone, where massive reaction takes place which releases a large amount of energy followed by the formation of flame.

In Fig. 8b, the existing structure is represented by the dash line and the proposed structure is represented by the solid line. Ethanol contains a hydroxyl group $(\mathrm{OH})$. Thus, the dissociation of $\mathrm{C}-\mathrm{C}$ and $\mathrm{C}-\mathrm{OH}$ bonds occurs in the $1 \mathrm{a}$ zone because in $\mathrm{C}_{\mathrm{n}} \mathrm{H}_{\mathrm{m}} \mathrm{OH}$ chemical structure, C-C has the lowest bond energy compared with others, followed by $\mathrm{C}-\mathrm{OH}$ bond [17]. The $\mathrm{C}-\mathrm{H}$ bond was broken in the $1 \mathrm{~b}$ zone due to the energy required to break the bond higher than $\mathrm{C}-\mathrm{C}$ and $\mathrm{C}-\mathrm{OH}$ [17], followed by the reaction of $\mathrm{H}$ with $\mathrm{OH}$ to produce $\mathrm{H}_{2} \mathrm{O}$ which releases heat energy. As a result, temperature $(T)$ increases, and the amount of fuel-oxidizer decreases at the preheat zone as shown by the solid line in Fig. 8b, while the number of reactions $(\mathrm{m})$ in the preheat zone is higher than the existing structure. Therefore, the burning velocity of ethanol is higher than that of LPG. The radicals in ethanol combustion are lower than in LPG, because the $\mathrm{H}$ and $\mathrm{OH}$ radicals are reduced to form $\mathrm{H}_{2} \mathrm{O}$. In the LPG combustion process, the partial preheating zone (1b zone in Fig. $8 \mathrm{~b}$ ) does not occur because of the absence of hydroxil group $(\mathrm{OH})$. Consequently, the number of radicals is higher than in ethanol. This causes the combustion speed of LPG to be lower than that of ethanol. The combustion characteristics of ethanol enriched with LPG are affected by phenomena that occur in zone 1b. In E95 and E90 compositions, the influence of the $\mathrm{H}_{2} \mathrm{O}$ formation is more dominant, but in E80 and E85 compositions the influence is smaller. Therefore, E95 and E90 compositions have a burning velocity higher than pure fuel, whereas E80 and E85 compositions between pure fuels. This seems to show that additional LPG (more than 10\%) absorbs more heat energy that inhibits the formation of $\mathrm{H}_{2} \mathrm{O}$. However, further intensive research with more precise instrumentation is required to give a more detailed insight into this phenomenon.

\section{CONCLUSIONS}

The main conclusions of this study are:

1. The premixed combustion of ethanol containing a hydroxyl group takes place in three zones. The dissociation of $\mathrm{C}-\mathrm{C}$ and $\mathrm{C}-\mathrm{OH}$ bonds occurs in the preheat zone due to low bonding energy. The $\mathrm{C}-\mathrm{H}$ bond dissociates in the partial preheat zone due to a higher bonding energy followed by the reaction of $\mathrm{H}$ with $\mathrm{OH}$ to produce $\mathrm{H}_{2} \mathrm{O}$ which releases heat energy. This makes the burning velocity of ethanol higher than that of LPG.

2. In the LPG combustion process, the partial preheating zone does not occur because of the absence of the hydroxil group. Consequently, the number of radicals is higher than in ethanol and the combustion speed of LPG is lower than that of ethanol.

3. The radicals in ethanol combustion are lower than in LPG, because the $\mathrm{H}$ and $\mathrm{OH}$ radicals are reduced to form $\mathrm{H}_{2} \mathrm{O}$.

4. The combustion characteristics of ethanol enriched with LPG are affected by additional heat energy that is released during the formation of $\mathrm{H}_{2} \mathrm{O}$ in the partial preheat zone. Additional LPG (more than 10\%) absorbs more heat energy that inhibits the formation of $\mathrm{H}_{2} \mathrm{O}$ therefore reducing additional heat energy.

Received 11 May 2016 Accepted 16 January 2017

\section{References}

1. Limayem A., Ricke S. C. Lignocellulosic biomass for bioethanol production: Current perspectives, potential issues and future prospects. Progress in Energy and Combustion Science. 2012. Vol. 38. P. 449-467.

2. Yang Y, Boots K., Zhang D. A sustainable ethanol distillation system. Sustainability. 2012. Vol. 4. P. 92-105.

3. Sannigrahi P., Ragauskas A. J. Characterization of fermentation residues from the production of bio-ethanol from lignocellulosic feedstocks. 
Journal of Biobased Materials and Bioenergy. 2011. Vol. 5. P. 514-519.

4. Zabed H., Faruq G., Sahu J. N., Azirun M. S., Hashim R., Boyce A. N. Bioethanol production from fermentable sugar juice. The Scientific World Journal. 2014.

5. Liao S. Y., Jiang D. M., Huang Z. H., Zeng K., Cheng Q. Determination of laminar burning velocity for mixtures of ethanol and air at elevated temperatures. Applied Thermal Engineering. 2007. Vol. 27. P. 374-380.

6. Egolfopoulos F. N., Du D. X., Law C. K. A study on ethanol oxidation kinetics in laminar premixed flames, flow reaction, and shock tubes. Twenty Fourth Symposium (International) on Combustion / The Combustion Institute. 1992. P. 833-841.

7. Broustail G., Seers P., Halter F., Moreac G., Mounaim-Rouselle C. Experimental determination of laminar burning velocity for butanol and ethanol iso-octane blends. Fuel. 2011. Vol. 90. P. 1-6.

8. Turner D., Xu H., Roger F. C., Natarajan V., Chen X. Combustion performance of bio-ethanol at various blend ratios in a gasoline direct injection engine. Fuel. 2011. Vol. 90. P. 1999-2006.

9. Al-lwayzy S. H., Yusaf T. Combustion of microalgae oil and ethanol blended with diesel fuel. Energies. 2015.

10. Patra J., Ghose P., Datta A., Das M., Ganguly R., Sen S., Chatterjee S. Studies of combustion characteristics of kerosene ethanol blends in an axi-symmetric combustor. Fuel. 2015. Vol. 144. P. 205-213.

11. Razus D., Oancea D., Brinzea V., Mitu M., Munteanu V. Experimental and computational study of flame propagation in propane-, n-butane- and liquefied petroleum gas-air mixtures. Third European Combustion Meeting ECM, 2007.

12. Liao S. Y., Jiang D. M., Gao J., Huang Z. H., Cheng Q. Measurements of Markstein number and laminar burning velocities for liquefied petroleum gas-air mixtures. Fuel. 2004. Vol. 83. P. $1281-1288$

13. Yun J. E. 1-D transient emission analysis of lpg engine catalytic converter with secondary air injection during cold start period of CVS-75 mode. International Journal of Automotive Technology. 2013. Vol. 14. P. 343-353.
14. Lee S. W., Cho Y. S., Choi W. C., Lee J. H., Park Y. J. Combustion characteristics of lpg and biodiesel mixed fuel in two blending ratios under compression ignition in a constant volume chamber. International Journal of Automotive Technology. 2012. Vol. 13. P. 1149-1157.

15. Liao S. Y., Jiang D. M., Huang Z. H., Zeng K. Characterization of laminar premixed methanol-air flame. Fuel. 2006. Vol. 85. P. 1346-1353.

16. Anggono W., Wardana I. N. G., Lawes M., Hughes K. J. Laminar burning velocity and flamability characteristics of biogas in spark ignited premixed combustion at reduce pressure. Applied Mechanics and Material. 2013. Vol. 376. P. 79-85.

17. Minteer S. Alcoholic Fuels. London: Taylor \& Francis, 2006.

18. Mahallawy F. Ell, Habik S. Ell Din. Fundamentals and Technology of Combustion. Oxford: Elsevier, 2002.

19. Ebbing D. D., Gammon D. S. General Chemistry, Ninth edition. New York: Houghton Miflin Company, 2009.

20. Glassman I., Yetter R. A. Combustion. Singapore: Elsevier, 2008.

Muh Nurkoyim Kustanto, I Nyoman Gede Wardana, Mega Nur Sasongko, Lilis Yuliati

\section{ETANOLIO, PRATURTINTO SUSKYSTINTOMIS GAMTINĖMIS DUJOMIS (SGD), LAMINARINIS DEGIMO GREITIS}

\section{Santrauka}

Eksperimento metu buvo vertinamas etanolio, praturtinto suskystintomis gamtinemis dujomis (SGD), laminarinis degimo greitis. Vertinimas atliktas cilindrinèje degimo kameroje, o degimo modelis buvo sferiškai besiplečianti liepsna. Rezultatai parodè, kad etanolio, praturtinto 5-10 \% SGD, laminarinis degimo greitis yra didesnis nei gryno etanolio ar SGD. Tai nutinka dèl $\mathrm{H}$ ir $\mathrm{OH}$ radikalų formavimosi pašildymo zonoje, kur reakcijos metu susiformuoja $\mathrm{H}_{2} \mathrm{O}$ ir išsiskiria šiluma. Tai pašildymo zonoje kelia temperatūrą, kas didina laminarinio degimo greiti.

Raktažodžiai: etanolis, SGD, laminarinis degimo greitis, išankstinis degimas 